Original article

\title{
A STELA FROM QEFT (QEFT R. N169, TT33)
}

\author{
El-Werdany, R. ${ }^{1} \&$ Sayed Ahmed, R. ${ }^{2}$ \\ ${ }^{l}$ Egyptology dept., Faculty of Archaeology, South Valley Univ., Qena, Egypt. \\ ${ }^{2}$ Egyptology dept, Faculty of Archaeology, Aswan Univ., Aswan, Egypt.
}

E-mail: radluxegy@yahoo.com

\begin{abstract}
The Stela of Qeft (Qeft R. N169, TT33) perhaps was erected at Dendera, and it moved to the storehouse museum of Qeft from chest number 6 in (TT33) at AL-Assassif, west bank of Thebes (Modern Luxor). It probably dedicated to Hor-Behdity and Hathor in a religious occasion at Dendara or elsewhere. The stela has a rectangular round top and divided into three registers with sacred symbols, scenes and empty cartouches in the first and second parts with no texts. Giving a date and determining the era to this stela will depend basically on the artistic styles and studying the empty cartouches after the general description of the stela and its components.
\end{abstract}

Keywords: Stela, Qeft, Hor-Behdity and Hathor, Empty Cartouches, offering of the Field (hnk-sht)

\section{Introduction}

This stela perhaps originally was erected at Dendera with no certain possible evidence. Currently, it is kept in Qeft's storehouse museum under number 169. Dedication: Being found in a place near Dendera, it is strongly suggested that this stela was one of many stelae dedicated to Hor-Behdity and Hathor in the festival or feast of

\subsection{Description of the stela}

It is a rectangular round topped ${ }^{(b)}$ [2] stela that is made of sandstone. It, also, has a lost part. It is $45 \mathrm{~cm}$ height and $33.5 \mathrm{~cm}$ width. It is divided into three registers; the first and the second are occupied with sunk-relief decorations and scenes, but the third one is empty. It is a well-executed and attractive stela; the craftsmanship is good but, unfortunately unfinished. It is in a good condition; the surface is carefully cut, prepared and their sacred marriage ${ }^{(a)}$ [1]. Source: It is also preserved under number (217) and is placed in a box labeled Qena Inspection of Antiquities, chest number 6 from the $33^{\text {rd }}$ storehouse at AL-Assassif (TT33), west bank of Luxor, with no date.

smooth. There are only few scratches and chippings on the edges. The design is well-conceived and executed. Additionally, no hieroglyphs texts are carved or inscribed on this stela. The upper register is ornamented with the winged sun-disk and two suspending cobras. On the second register, there is a scene that shows a king offering sht-sign or the "field-offering" to the god Horus and the goddess Isis. There are also two empty cartouches in a 
vertical position $\underline{0}$ and the name of Horus in front of the king's face as the only and unique hieroglyph sign
These empty cartouches and the name of Horus refer to the ruler king ${ }^{(\mathrm{c})}[3]$.

\subsection{Detailed description of the decorations and scenes}

The detailed study of the stela is divided into three unequal-spaced proved that it is carved on one-face and parts, fig (1-a, b, c), as follows:
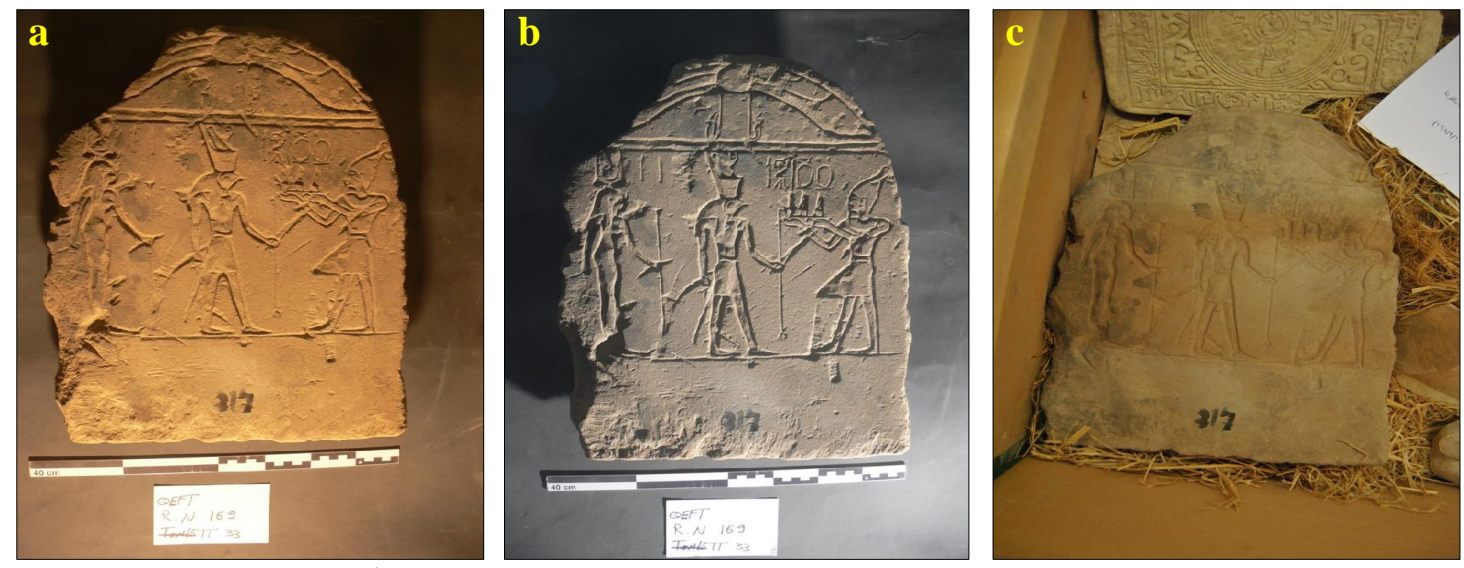

Figure (1-a, b, c) Shows the stela of Qeft

\subsubsection{The upper part}

This part, fig. (2-a) occupies the same round-topped space of the stela. Here is a decoration of the so-called [4], "The winged-disk" 'py $\square$ 48 victory of Hor-Behdety over his enemies (See comment no. 1), fig. (2-b). From the central part of this decoration (the sun-disk itself), two symbols are hanging down or suspending: are, also, written: 8 ; [2]. All of these signs could be read nswt-bity "king of Upper and Lower Egypt“(f) [6]. The first symbol
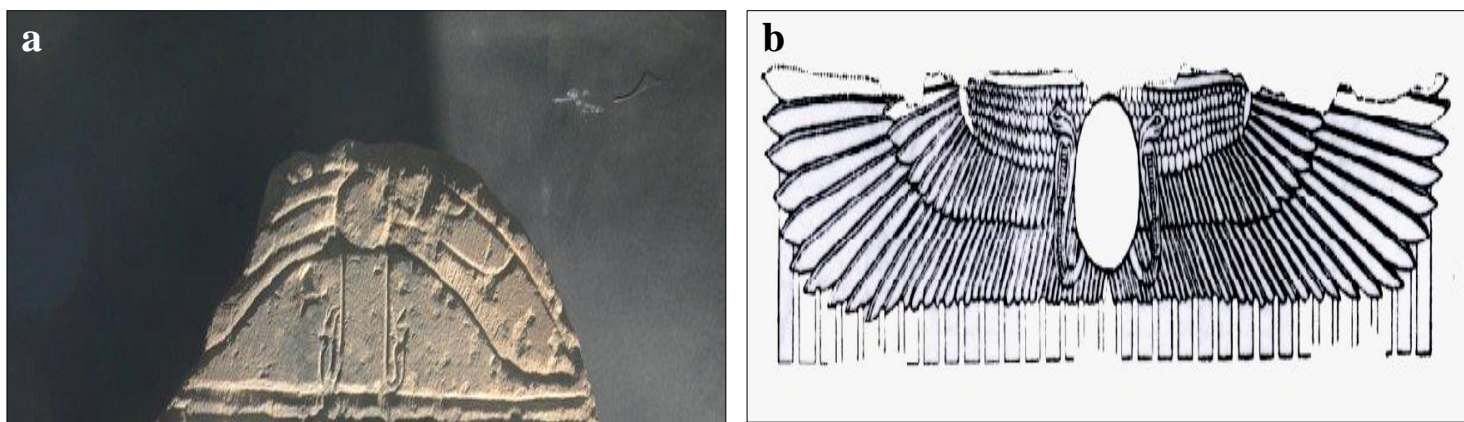

Figure (2) Shows $\underline{\mathbf{a}}$. the first upper part of the stela shows the decoration of the winged disk, $\underline{\mathbf{b}}$. decoration of the winged sun-disk, symbol of Hor-Behdity's victory over his enemies. Sauneron, Esna II, P.5.

\subsubsection{The middle part}

The scene of this part, fig. (3-a) begins from left to right as follows: 1- (on the right side) is a serpent wearing the white crown of Upper Egypt (South) $h \underline{d} t$, šm $m^{c} s, w r r{ }^{(\mathrm{g})}$ [7]. It is the sacred symbol of the goddess Nekhbet, mistress of Nekheb (El-Kap) ${ }^{(\mathrm{h})}$ [8]. The second (on the left side) is a serpent wearing the red crown of Lower Egypt

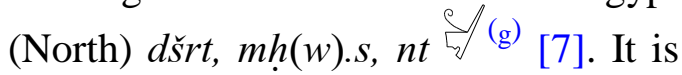
the sacred symbol of the goddess Wadjet, mistress of Buto (Tall AlFaraeen $)^{(i)}$ [9]. Below there is a two lines-frieze to separate this part from the next one. 
crown, the royal beard and the royal skirt (kilt, apron) 床 šndyt, šndwt ${ }^{(\mathrm{g})}$ [7]. The royal personality raises his arms with hands in front of the face carrying a symbol of the field. It is the offering of the field hnk-sht $-\frac{111}{-2}$ (See comment no. 2), fig. $(3-b)^{(j)}[10]$. 2- He presents this offering to the god Horus-Behdity ${ }^{(\mathrm{k})}$ [11] in a human body with a falcon-head. Horus wears the double-crown of Upper and Lower Egypt shmty $y^{(\mathrm{g})}$ [7] and a short-skirt. He seizes $w 3 s$-scepter $7(\mathrm{~g})$ [7] by his left hand and by his right hand he seizes the ' $n h$-sign $f^{(\mathrm{g})}$ [7]. 3A goddess is standing behind Horus that is generally depicted in the appearance of Hathor or Isis. She wears a garment and a hair wig with an ear of a cow. This suggests that she is the goddess Hathor mistress of Dendera ${ }^{(1)}$ [12]. She wears her distinguished and famous crown (i.e., the sun-disk) between tow horns of a cow. On her front, there is a standing uraeus (cobra). She holds by her left hand the $w 3 \underline{d}$-scepter $\nabla^{(\mathrm{g})}$ [7] and by her right hand she holds the ${ }^{`} n h$-sign.
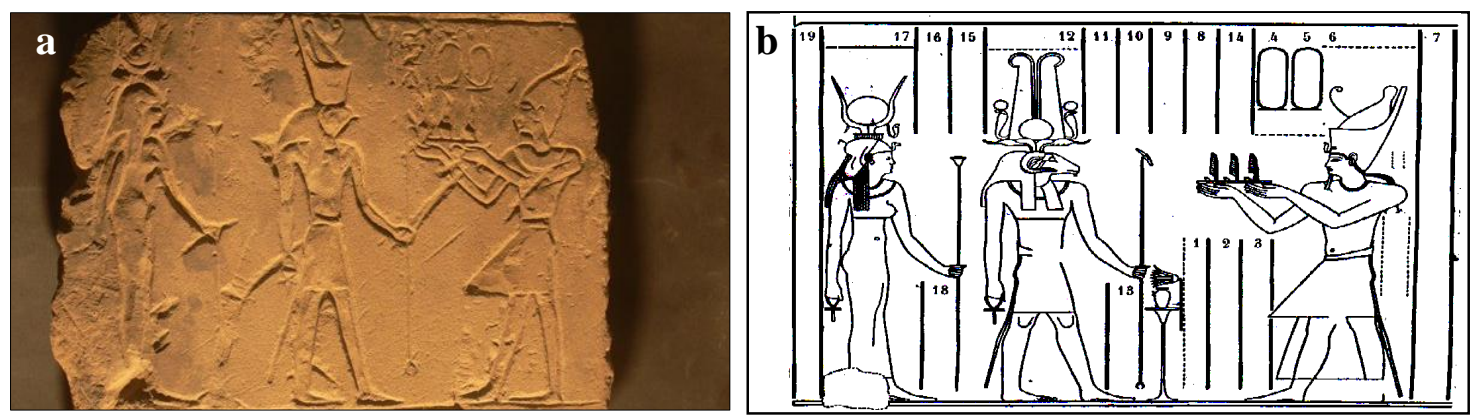

Figure (3) Shows a. the second middle part of the stela shows the king offering sht (the field)-symbol to Hor-Behdity and his counterpart Hathor, $\underline{\mathbf{b}}$. the King Ptolemy VI (Philomator) (170-164 B.C.) offers the fields to khnum and Nebtuu. Sauneron, Esna II, P.74.

\subsubsection{The lower part:}

There is a single line that separates this part and the upper part, fig. (4), unfortunately, the last part is prepared to inscribe a hieroglyphic text as explaining for the above scenes and empty and unfinished. It was probably decorations.

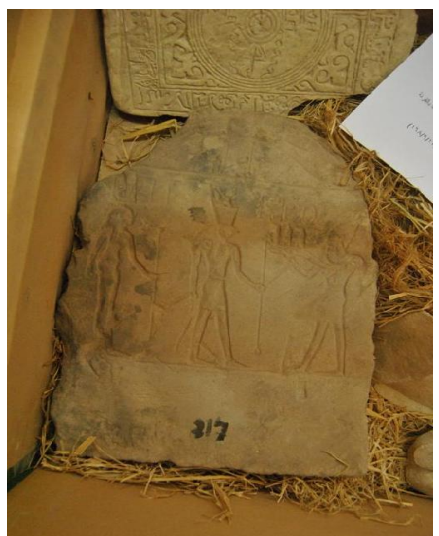

Figure (4) Shows the third empty lower part of the stela.

\section{Dating by the distinctive artistic characters}

From the artistic characters of the scenes and the executive styles of the reliefs concerning the personages, the facial features of the king and the goddess's; a detailed fat face and body, suggest that the scenes of this stela may be dated back to the Ptolemaic era. In the following pages, we try to give the reader a completed idea about the empty cartouches on which we will depend mainly before giving this stela an accurate date. 


\subsection{The empty cartouches}

The first appearance and occurrence of the empty cartouches (cartouches of Akhenaten, $18^{\text {th }}$ dynasty, New Kingdom). The empty cartouches of Akhenaten that were found on two stone columns from Amarna era are now in the Egyptian Museum; the first stone, fig. (5-a) shows seven empty cartouches and the second shows Akhenaten and Nefertiti under the solar beams of Atun, there are four empty cartouches above them in addition to the sun-disk of Atun, fig. (5b). Every empty cartouche represents a king's name and can be read $r n$ instead of $m n s ̌$ and it has the importance of the

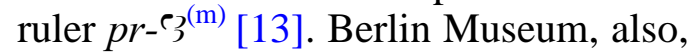
holds two pillars with small empty cartouches and they are not suitable for any king. They were made small and empty for a certain purpose like personifying Akhenaten as Shu. It is known that the close connection between Shu and the king is one of the most usual connections in Amarna era because the god Shu has played a vital role in Amarna texts. He has appeared in many places equal to the king Akhenaten in the tombs of Tell El-Amarna. Therefore, the king is shown, here, with a four- feathered crown which the king made as a personification of himself with Shu fig. (5-c). The incarnation of Akhenaten as Shu is shown also on a stone in Berlin Museum (Nr. 2045) and on the black beetle in London Museum (Uc 2233). The figures show Akhenaten bearing and raising up two cartouches to Atun, in a situation for Shu at lifting up the sky, who raises the golden name of Horus wts $r n n$ 'Itn "Who raises names of Atun". This meaning has been copied in arts. So the link between the empty cartouches and Shu was found since the New Kingdom; writing name of Shu on an empty cartouche means "space". In addition, the empty space between sky and earth equals the empty part in the cartouche. The name of Shu was written in the Ptolemaic period with two empty cartouches 00 or 07 . Writing for the rulers with two empty cartouches both of them makes an effect on the other. The connection between the king and Shu and the two empty cartouches has a religious background reflecting the ruler's dominion that represents Shu's sovereignty on earth ${ }^{(\mathrm{m})}[13]$.

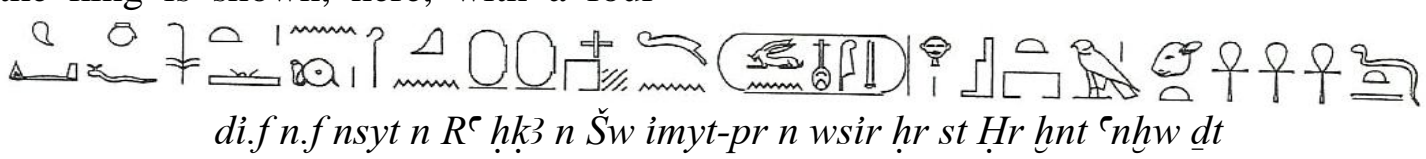

"He gave to him kingship of Re, rule of Shu, inheritance of Osiris, wenen nefer makheru, on the throne of Horus among the livings" ${ }^{\prime(n)}$ [14].

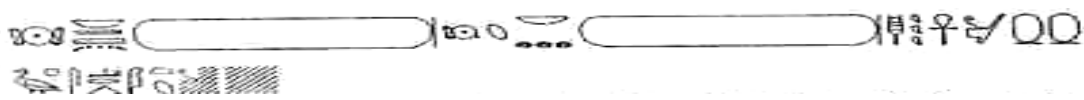

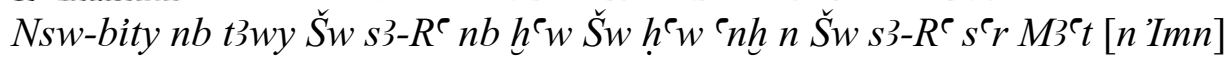

"King of Upper and Lower Egypt, lord of the two lands, the ruler (Shu) son of Re, lord of crowns, the ruler (Shu), the living representative of Shu, son of Re, who raises (= receives) Maat [of Amun]"(o) [15].

In the second example, the expression $h^{\complement} w \quad n$ ' $n h$ describes "the incarnation of the god" the king as incarnation of Shu and son of Re. The king leads Maat-offering as a living incarnation of Shu in the first life $h^{\complement} w$ ' $n h n$ S $w$. Furthermore, the function of the king equals that of the eldest son of $\operatorname{Re} \check{S} w s 3 R^{\mathrm{r}^{(\mathrm{p})}}[16]$. These meanings have been repeatedly emphasized in the Egyptian Antiquities. In addition, the royal value which is given by Shu; coronation of the king is held by him and sitting on his throne as his successor. Shu, as a son of Re, takes the same rank of the king as well as the king and the opposite. This gives him importance and position. The close 
connection between the incarnation of the king Akhenaten and the god Shu exists in the Egyptian antiquities. The two stones in Berlin Museum show the

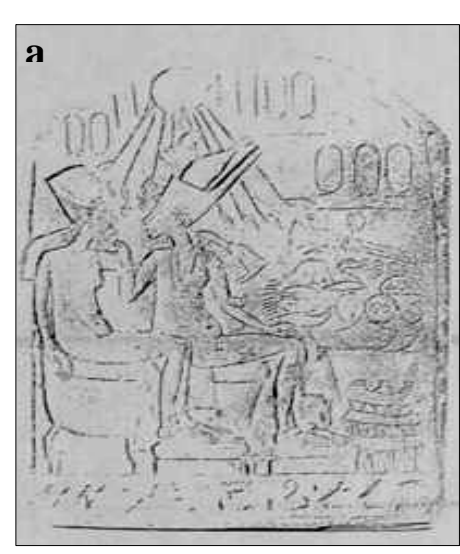

names of Akhenaten, Nefertiti and Atun with empty cartouches that could be read $\check{S} w$ and may indicate the importance of "the ruler" ${ }^{\text {(m) }}$ [13].
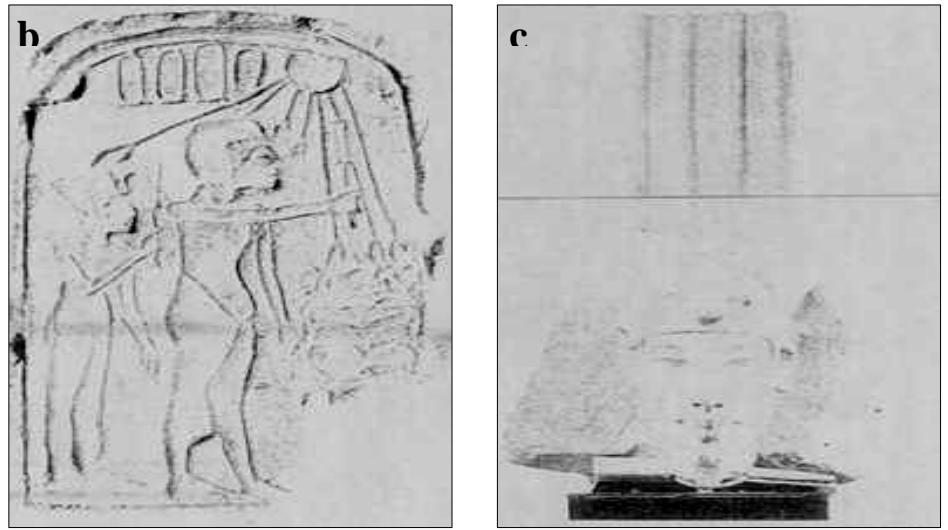

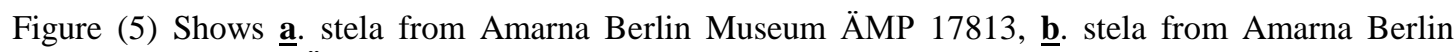
Museum ÄMP 25574, c. head-dress (crown) of Akhenaten, Cairo Museum, JE 98894.

\subsection{The meaning of the empty cartouches}

\subsubsection{The empty cartouches of Osiris}

The empty cartouches of Osiris on the ceiling of the $3^{\text {rd }}$ eastern chamber of the Osirian chapels and on the roof room of Dendera temple represent the first attribute. They exist in the decorations' frieze with various representations of Osiris as a sun-disk or a winged beetle together with representations of Nekhebet and Wadjet. The inscriptions of the frieze ends with a cartouche of Osiris with his private name: wnn-nfr $m 3^{\complement}$ hrw. It was found one time destroyed and was left empty 9 times:

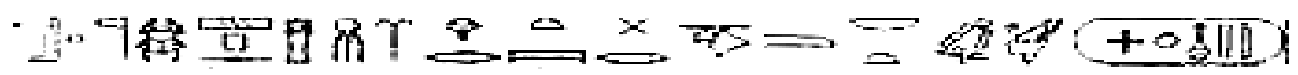

Wsir ' $b b$ šps psd $m$ hrt wr šfyt $m$ nb 3tf nswt-bity Wnn-nfr m $3^{c}-h r w$

"Osiris, the venerable beetle, who shines in the sky, great of awesomeness as lord of Atef-crown, king of Upper and Lower Egypt, wenennefer makheru, the late"(q) [17].

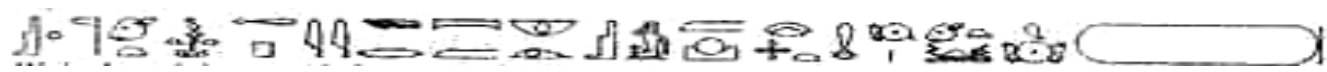

Wsir hnty-Imntt 'py r pt $m$ hb ir st.fm 3ht he.tw mi $R^{\complement}$ hnt wi3. fnswt-bity (empty)

"Osiris, who is in the beginning of the west, who flies to the sky in the feast, who takes his place (= throne) in the horizon (= temple), who appears as Re in his solarbark, king of Upper and Lower Egypt (empty)|" (r) [18].

Within the same context, another empty cartouche exists on the ceiling of the second eastern chamber of the chapels of Osiris:

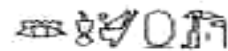 \\ ir sntr n nswt-bity (empty)| wsir}

"Making incense for the king of Upper and Lower Egypt (empty)|, Osiris" ${ }^{(\mathrm{s})}$ [19].

\subsubsection{The small empty cartouches}

The scene of the empty cartouches, in the form of $\underline{0}$, represents the second attribute, as a hieroglyphic sign. It could be read as a word, unlike large cartouche that is a place for keeping the royal name ( ) $)$. We found these scenes in different places as follows: 
- In the inscription of the upper southern side of the chapel ḥt-Sššt

$$
\begin{aligned}
& \mathbb{8} 900 \mathrm{Q} \text { ? } \\
& \text { hs.s nsw-bity } \underline{d} d t
\end{aligned}
$$

"She forever praises the king of Upper and Lower Egypt, the ruler"(s) [19].

- In the decoration frieze of the upper southern side of the chapel, $p r-w r$.

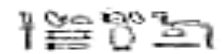 \\ $\underline{h} w$ s $3 . \underline{t}$ mry. $\underline{t}$ s $3 R^{\mathrm{C}} \underline{0} \underline{d} t$}

"Protect your son, your beloved, son of Re, the ruler, forever" ${ }^{(t)}$ [20].

- In the decoration frieze of the roof chapel:

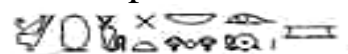

$$
\begin{aligned}
& N \text { sw-bity } 0 \text { mry Ht-Hr wrt nbt'Iwnt irt } R^{c}
\end{aligned}
$$

"King of Upper and Lower Egypt, the ruler, beloved of Hathor, mistress of Dendara, eye of $\operatorname{Re}^{\prime(t)}$ [20].

- In the eastern room of the Osirian chapels on the roof:

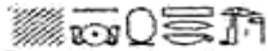

[ii].n $n s w$-bity 0 hr.k wsir

"King of Upper and Lower Egypt, the ruler? [came] before you, Osiris" (u) [21].

The small cartouche, as a different meanings in the Ptolemaic hieroglyphic sign, has been used in period, and in distinguished vocabularies.

2.2.3. Readings of the sign 0

\subsubsection{1. $r$ as a name of a god}

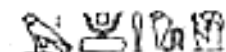

$H r$-wpw rn hm.k

"Horus-the-judge is the name of your majesty" ${ }^{(\mathrm{u})}$ [21].

2.2.3.2. $r n$ in the writing of Horus's title

$$
\text { m33it.firy rn.f ds.f/III }
$$

"(Horus)..., who sees his father, who created his name by himself"(u) $[21]$.

\subsubsection{3. $r n$ as a name of a king}

$$
\begin{aligned}
& \text { PR:O西- } \\
& \text { smn.n.i rn.k } m \text { nswt }
\end{aligned}
$$

"I fixed your name as a king"(u) [21]. In a role of goddess Seshat.

2.2.3.4.rn as a name of a place

$$
\text { broes: }
$$

rn nw niwt th

"The names of this city (=Dendera) ${ }^{(\mathrm{u})}$ [21].

2.2.3.5. $m n \check{s}$

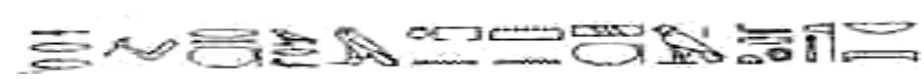

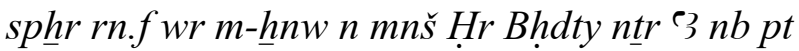

"Your great name is recorded in a cartouche (as) Horus Behedety, the great god, the lord of the sky"(u) ${ }^{(21]}$. As a title of lhy

$$
\text { 콩 or } \approx \square
$$

$n b$ w3d.ty $n b$ mnš

"Lord of the two eyes, lord of the cartouche" (u) [21]. 
N.K., as a name of god Shu means "spacc?". Since the Ptolemaic period, the name of Shu has been written with two vertical cartouches 00 or $\unrhd 0^{\circ}{ }^{\text {(c) }}$ [3].

\title{
2.2.3.7. Wnn-nfr as a name of Osiris
}

\author{
ת. 70 Q \\ Wsir Wnn-nfr m3c-hrw \\ "Osiris, Wenen-nefer maacheru, the late"(c) [3].
}

\subsubsection{8. - as a determinative for $k$ 3 with the meaning of "name"}

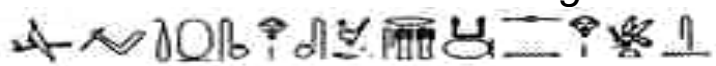

hti.tw rn.sn hr.sn $n$ bi3 $r$ sdd k3.sn hr k3t.sn

"Their names were inscribed with metal tools; their ka-names are still remaining in their deeds" (u) [21].

\subsubsection{9. - as a determinative for $\check{s} n$ with the meaning of "circle":}

$$
\begin{gathered}
\text { sircle of the sky" }{ }^{(c)} \text { [3]. } \\
\text { "Cist }
\end{gathered}
$$

\subsubsection{The connection with Shu in the Ptolemaic period}

Here, we will try to give dating

to this stela by studying the two vertical cartouches in front of the king's face in the Ptolemaic period. From the beginning of the Ptolemaic era, the name of god Shu could be written with two empty cartouches that were primarily referring to the king. By the end of Ptolemy IV's reign and the beginning of Ptolemy V's reign, some important and notable scenes on the door of the western corridor were discovered, leading to the temple zone at Edfu, fig. (6-a), they do not refer to the cartouches and they are completed empty. A scene shows the king offering a nmst-jar to the god Horus, who bears the title: $h m n \check{S} w$ "majesty of Shu"(u) [21]. The king, in this scene, is referred to as "majesty of Shu" because the rule of the king was not certain or emphasized. This is expressed by leaving an empty space, perhaps with two cartouches. Shu, in this case, equals the king and his representative. This phenomenon appears only in this site from this period, so the connection draws the attention to the two empty cartouches. The link has been established by assembling the god's name $^{(\mathrm{c})}$ [3]. Additionally, they are connected with the god Osiris and the pr-?3 cartouches which belong to king Ptolemy XII at the temple of Edfu. They show the likeness of "Osiris the king or the ruler" ${ }^{\prime(c)}$ [3] meaning. This phenomenon is also found for well-known rulers where they were applied on the attributes described by the author. For example, the stela of Akhenaten from the $18^{\text {th }}$ dynasty, fig. (6-b), the satrap stela in the Late Period and in the Ptolemaic Period, fig. (6-c) and on the Nobaria stela, fig. (6-d). Furthermore, there were other locations in the temple where the cartouches remained empty in the end of Ptolemy $X$ 's reign in the north-east aisle in the open court of Edfu temple ${ }^{(\mathrm{u})}$ [21]. They, also, contain empty cartouches for a number of the ptolemies reflecting the struggles and political unrest among the members of the Ptolemaic family ${ }^{(\mathrm{v})}$ [22]. Furthermore, there are empty cartouches for Cleopatra VII, her two brothers Ptolemy XIII, Ptolemy IVX and her son Ptolemy XV (Caisarion) at the temple of Dendara $^{(u)}$ [21], fig. (7-a, b). 

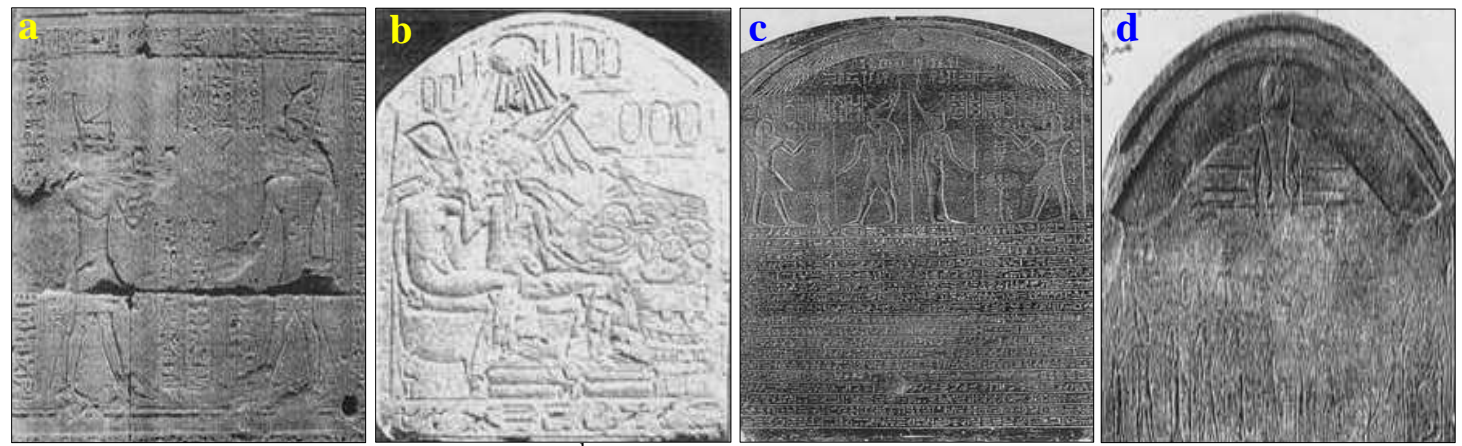

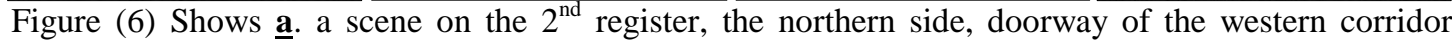
which leads to the temple zone at Edfu, $\underline{\mathbf{b}}$. a stela from Tell-Al Amarna (Berlin Museum N.

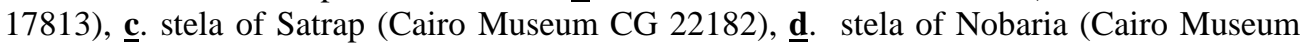
CG 22188).
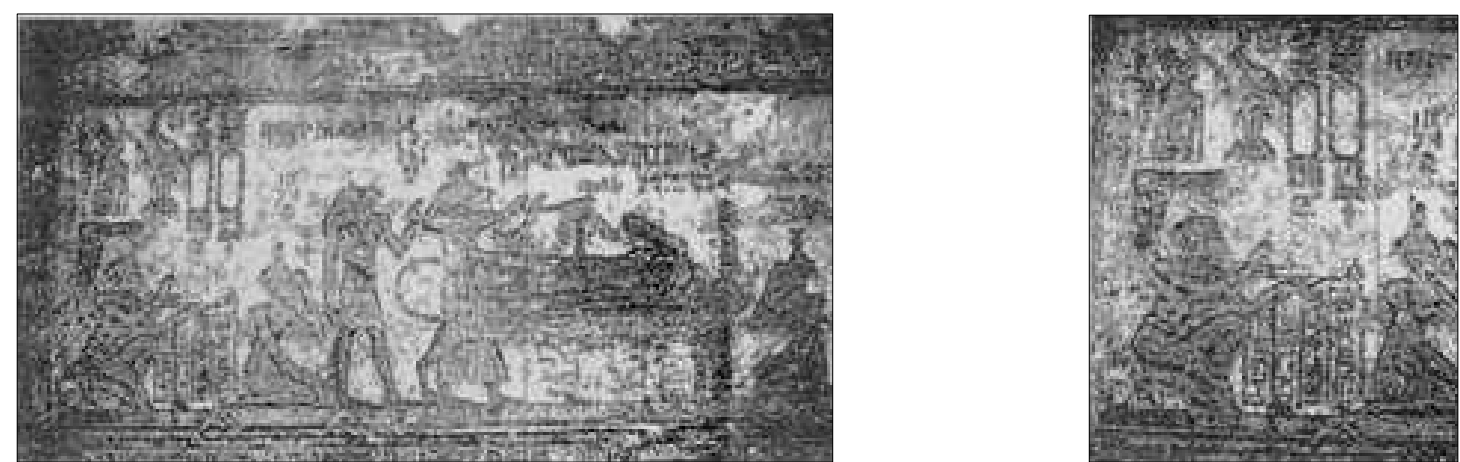

Figure (7) Shows a. a scene of Kaisaron (Ptolemy XV) on the western wall, $3^{\text {rd }}$ room (west), roof chapels, temple of Dendara, $\underline{\mathbf{b}}$. details from the same scene

\section{Discussion}

\subsection{Comments on decorations and scenes of the stela}

\subsubsection{The winged sun-disk decoration}

'py "the winged disk" (w) [23]

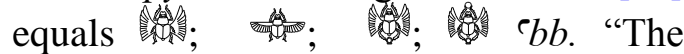
winged beetle or falcon"(w) [23]. 'py is the sun disk, endowed with wings to enable it to fly, is derived from the verb 'py "to fly". It is derived from the earlier 'pi (pyr.) "to go" $\mathbb{A}$. When used for falcons, it is given a determinative wing to represent the idea of flying. Because there are a large number of texts in praise of Horus as a falcon and as 'py the noun occurs often at Edfu. The verb "to fly" may sometimes be masked by the writings [23]. Ii is a Heliopolitan concept. Additionally, the image of the winged disk was depicted from the $6^{\text {th }}$ Dynasty (Old Kingdom). Sinai's inscription of Pepi I (Wadi Magharah) shows the name of the king while he punishes and subjects the great of the Bedwins and it is already called Behdety. The equation of the winged disk with Behdety cannot be dated firmly but this concept is central to the Edfu dogma. The winged disk represents the sun uniting the two lands; its two wings protecting Upper and Lower Egypt; and the two uraei looking north, south and in the middle on Heliopolis. When the sun disk and the falcon Horus are united, the disk represents the king and the power of kingship. Hence, the myth of Horus provides a mythological explanation of uniting Behdety and the sun disk when the foes of Re Harakhty appears, Behdety flies ( $\left.{ }^{\prime} p y\right)$ to heaven as The betle, as the rising sun, represents ${ }^{\prime} p y$. This caused confusion with the ${ }^{\circ} b b$ winged beetle. The a common a decorative element on the doors. Additionally, it is used as a constant reminder of the presence of the sun god and the power of kingship ${ }^{(x)}$ [24]. The winged sun disk 'py $w r$ is related to Edfu. It has been inscribed in a long hieroglyphic text on the walls of 
Edfu temple as one of the most important myths of the temple. Its texts occupy the surfaces of the inner parts of the eastern and western walls surrounding the temple ${ }^{(\mathrm{y})}[25]$. It was narrated that the god Re-Hor-Akhty had resided in Edfu Nome and the god Horus the Behdetian was accompanying him in his boat to attack the enemies. Because Horus helped him to win, the god ReHor-Akhty ordered to inscribe and carve his icon on the entrances of the temples where he commanded the god Djhwty, saying: "you'll make this winged disk everywhere I rest, and in everyplace of the gods of Upper Egypt and those of Lower Egypt". Henceforth, the symbol decorating all the doors and portals in the temples has begun, emerged, spread and continued; it is the winged sun-disk [25]. This symbol ornaments the upper lintel or ceiling of rooms and halls. It appears on the inner parts of the temples' entrances. Hence, this legend provides us with an interpretation of the appearance of Horus the Behdetian in the form of the winged sun disk on the front parts of the temples. In spite of registering the myth of the winged sun disk in the GrecoRoman period, many researchers discovered a recording of past accidents

\subsection{The offering of the field (hnk-sht)}

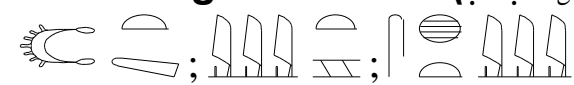

sht, field, marsh, marchland, country; shty peasant, fowler ${ }^{(\mathrm{g})}$ [7].

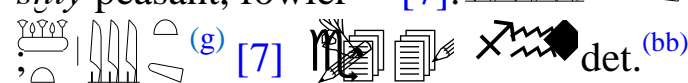

[28]. The sign sht shows reeds growing side by side with shoots between them and originally referred to marshland or reed thickets where birds and fish were caught. The extent of this "marshland" and its use, however, varies in Egypt because when the inundation receded the whole the country a huge marsh area would be left behind. Consequently, the term sht could apply to all of this land and the land which was flooded to produce plant crops. During the year, the sht proper would be in the form of in the ancient Egyptian history there. They, even, vary in defining these events and their dates ${ }^{(z)}$ [26]. Some researchers think that the myth describes the destruction caused by Horus the Behdetian against his father the sun-god's enemies. Furthermore, with a strong influence similar to the myth of Osiris-Horus, Horus the Behdetian has been equaled with Horus son of Osiris and Isis. It was supposed that the struggle was against his personal enemy the god Set in order to revenge for murdering his father Osiris to have and gain his legal right in inheritance of ruling Upper and Lower Egypt. He, also, became the innocent victorious before the convention of the gods ${ }^{\text {(a) }}$ [27]. The word 'py "winged sun-disk" could be written in various forms:

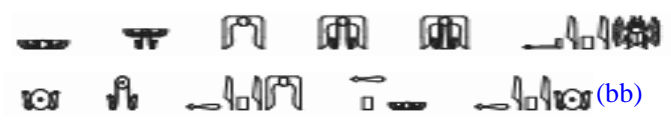

[28]. It represents the king himself where the hieroglyphic sign 1 writing the king's title: Nswt-bity "King of Upper and Lower Egypt". It could be written in other forms:

or of of of of of this has occurred since the $19^{\text {th }}$ dynasty (New Kingdom $)^{(f)}[6]$.

marshes by the river and there would be more extensive marshes all year round in the delta. The ritual of offering $s h t$ (hnk-sht, wdi-sht, init-sht) has a symbolic meaning. At the Heb-sed, the rite allows the king to take possession of the four corners of the world. Thus sht is all land flooded In addition, all the land is worth having because of its productive capacity meat as well as vegetables and corn. The offerings in the temple represent giving all the productive areas of Egypt to the god and everything which depends on that land. As a result, donation stele of the late period often depicts this offering. Furthermore, donation texts in Edfu begin and end with a hnk sht rite. In return, the king is given the land producing 
crops to fill the granaries; all provisions and parts of Egypt are under his control. This ensures that the god who owns all the productive lands benefits the king in kind. Hence, the king control lands and is able to widen their boundaries so that more is provided for the god; he rules the land. When crops are harvested, store houses are filled. Therefore, the sht offering encapsulates the role of the king in his relationship with the gods. It also represents the successful agricultural cycle from flood to bumper harvest. On presenting the offering, the king wears the double crown showing his rule of Upper and Lower Egypt. This offering is depicted as sht rising upon the hands of the king. It, also, represents the productive nature of the god and the donations of land offered to him ${ }^{(\mathrm{cc})}[29]$. It is a general term for productive lands in the Nile valley ${ }^{(\mathrm{dd})}$ [30]. In the temple of Dendera, the king says to Hathor: di.i $n . k$ sht $h r m s . i \quad n . k k 3 w$ "I give to you field and I offer to you offerings"(ee) [31]. The offerings of sht open and close the text of donations. In the late period, this rite was held and performed during the festival of sed $h b-s d$. It symbolizes enduring king's possession of the four regions of the universe (i.e., four cardinal points). sht, almost used in an emblematic way; as a symbol of "that which is produced by the fields". Linguistically, sekht is used for marsh land, fields and countryside. Derivationally, it is shty "peasant", but as an iconographic it is usually interc-hangeable with the $h t p$ or $\sqrt{-}$ offering sight and its connotations. Because of the crops they provide, fields, themselves, could be used as a symbol of offerings. Thus, sht is sometimes personified as a goddess bearing offerings in the temple of Amenhotep III at waddi ul-sebu'a, where she appears accompanying male fecundity figures. She is depicted carrying and offering a mat laden with ducks, goslings, eggs, and tilapia. She wears the sh.t sign upon her head, and is named in the accompanying inscription which states that she brings $h w d f j w$ "food and provisions" for the god. In addition, sht was used in other symbolic ways. A stela of the early Greco-Roman period shows the Ptolemy ruler, son of lagos, presenting the "field" sign to the god Harendotes" Hours, protector of his father". The motif of offering is based on earlier examples. Furthermore, the classical inscription before the king directly links the giving the fields' offerings to his hope of receiving the gift of life. In Metropolitan museum of art, a stela of the noble Maat from the $11^{\text {th }}$ dynasty, offering shows the deceased person in front of an offering table with various offerings, e.g. a foreleg and ribs of beef, a duck and various other goods heaped above the conical half-loaf of bread. Although the halfloaves are quite clearly reeds-which approximate the shape of the required offering, they suggest a much fuller range of "Offerings of the field". The concept of the field was, also, expressed in various afterlife beliefs. For example, in the book of imy- $d w 3 t$ "i.e., that which is in the underworld", the sun god "Re" is said to distribute "fields of offerings" to the underworld's inhabitants on his nightly journey. In chapter (145) of the book of the Dead, the domain of Osiris is called the "field of Reeds" or i3rw. According to the Osirian doctrine, the deceased was believed to work and live in these fields; planting and harvesting the bountiful crops of the field "field of the west", as they were also called was common Vignettes of chapter 109 of the same book, also, express the hope of an abundant afterlife. In the book of Gates, the divisions of the underworld are sometimes called "fields" and they were illustrated on the walls of many tombs of the kings of N.K. However, sht sign is rarely used in the composition of the vignettes or the tomb paintings that tend to be more naturalistic in the portrayal of these concepts ${ }^{(\mathrm{ff})}$ [32]. The offering of the field is one of the familiar offerings in the ancient Egyptian temples along 
the ancient Egyptian civilization and in the registers of the Greco-Roman temples $^{(\mathrm{cc})}$ [29]; it is connected with the annual inundation. It is one of the greatest symbols of innate fertility that means "the abundance" by which it takes out from the goods of fields and enriches the two lands. Consequently, stores are full of different crops of which the largest portion goes to the gods in the form of offerings and dedications ${ }^{\text {(gg) }}$ [33]. It is frequently reported, in the texts of the Pyramid, that the flood is a reason of happiness, not only for people but also for gods because their offerings depend on the flood gives from the fields Products $^{\text {(hh) }}$ [34]. In addition, some plants such as Nilotic plants are a source of renewing life; flowers do not grow until the flood come, so they are connected with renewing life. In conclusion, we could say that the offering of the field represents complet-eness of the Egyptian products. The king, in this offering, bears titles or epithets connected with inundation god $H^{\top} p i$ and with the flood which irrigates the fields. Hence, he is the son of Nun and the one who was born from
$H^{\prime} p i$. Also, he is the lord of fields and the one who has control over them. Consequently, he is deeply related to these gods because they supply the fields with water. Because of these gods products become ideal with excellent attributes; they are pure and free from blights. The offering of the field gives a special impression that are controlled by gods and the king who offers them; even learning agriculture and using fertilizers is attributed to the god Osiris. So, fertility of the land and growing plants is a divine gift from gods to the human beings on earth. This is clearly mentioned in the texts that always emphasize that the gods to whom this offering (shtfield) is presented. The gods provide such things and appoint the king, as their successor, to rule. Here, the king expresses his gratitude towards the gods by offering them gratuities. By the way, the offering represents the control of gods offered to them the offering- over all the products of the agricultural lands and alternatively over all life types on earth.

\section{Conclusion}

Studying a stela from Qeft led to some scientific remarks which could be concluded as follows: 1-This stela perhaps originally was discovered in Dendera. Then it was stored in a big storehouse (TT33) in the west bank of Thebes. It is now in the main storehouse of Qeft. 2This stela was created and devoted to the goddess Hathor lady of Dendera, and the god Horus the Behdetite lord of Edfu. This might be in celebration of their annual sacred marriage. 3- Dating of this stela is really a big problem because it has no texts, inscribed cartouches or frank names with a clear evidence to help in giving an accurate date. 4- After carrying out a detailed study of its components; religious symbols, human figures, empty cartouches, decorative elements and the kingly offering to Hathor, two directions are proposed in determining its date. 5- Its distinctive artistic styles suggest that it belongs to the Ptolemaic era. 6- Comparing the parallel texts of the empty cartouches and scenes of field-offering (hnksht) in Edfu with those in other places helps in identifying the Ptolemy king who is depicted as offering to Hathor in the stela. It may be at the end of reign of Ptolemy IV (philopator) (522205 A.D.) and at the beginning of reign of Ptolemy V (Epiphanes) (203-180 A.D.), Ptolemy VI (philometor) (180-145 A.D.): (parallel scene, figures 6, 7), Ptolemy IX (Soter II-Lothoros) (11681 A.D.) or Ptolemy XII (Neos Dionysos- Auletes) (80-51 A.D.). However, no confirmatory evidence is provided. Finally, According to the parallel scenes of the field-offering in Dendera and Edfu temples, we may suggest that this stela maybe dated back to the reign of the king Ptolemy IX (Soter II)?.

\section{Endnotes}

(a) The feast of the sacred marriage between the god Horus-Behdity (Edfu) and the goddess Hathor of Dendera is the " the festival of a beautiful and happy meeting " where Hathor starts the journey from her temple at Dendera every year to spend 15 days at the temple of Edfu 
with her husband Horus. This journey was a happy occasion and a pleasant event with the participation of the public. Hathor leaves her temple before 5 days of the full-moon; Christophe, CdE (1955), pp. 3, 35, 42; Allam, MÄS.4; Bonnet, Rärg, ss. 277-282.

(b) For more information about the round-topped stelae, see: Hölzl, R., in: Atti del VI Congresso Internazionle di Egittologia, pp. 285-268.

(c) For more details about the empty cartouches, see: El damaty, in: GM. 207, ss. 23-36; OLA. 150, pp. 501534; in: Honor of Jack A. Josephson, pp. 79-81; Deutsches Archäologisches Institut Abteilung Kairo, ss. 81-101.

(d) Winglyph

(e) Faulkner, Middle Egyptian, p. 41.

(f) Daumas, Valeurs III, , pp. 442-443.

(g) Faulkner, Middle Egyptian, pp. 54, 64, 114, 125, 181, 244, 266, 270, 507, 595; Gardiner, Egyptian Grammar, p. 480, 481, 504, 509; 591, 612 signlist: 14 (trees and plants M 20: reeds growing side by side); Pyr. 275; Urk. IV. 462, 13; Daumas, Valeurs, II, 414,419-420 ,III, p. 617, 618,619, 638, 646-647; WPL., pp. 150, 544; Wb. II, 331 (13-15), IV, 229 (8)-231(7).

(h) Nhbt - the Nekhebt, a goddess as a personification of the female vulture, Wb. II, 309 (1). Nhbt +1=3 ; $+10,+10,7 \pm d$, endings of her name: A, o the goddess Nekhebt of ElKap and the protectress of Upper Egypt, Wb. II, 309 (7). Nhbt HDt Nhn $+\lambda^{\circ}+0$ the so-called title of the goddess Nekhebt: "Nekhebt the white one of El-Kap", Wb. II, 309

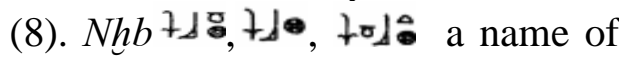
the cult center of the goddess Nekhebt, El-Kab (Eileithy-iospolis),Wb. II, 309 (2). Her name means "One who follows $N h n$ " or "One who belongs to Nxb". Some researchers thought that she was worshipped at Naqada I where she was depicted on the lion and vultures pallet and on the pallet of fortresses and booties (spoils). In the time of Naqada II and the proto-dynastic era, she was the protectress goddess of Uppr Egypt. The kings of the unification considered her as their nurser and protectress. El-Kab was her cult center in the 3rd nome of Upper Egypt and she has a cult chappel there. Nekhbet appeared in the figure of the female vulture upon her head the white crown; her sacred symbol. She was depicted as the protectress of the king flapping her wings on his head. Sometims, she was depicted in the form of a snake or serpent together with the goddess Wadjet upon a basket or $n b$-sign (the nbty-title). Vanvoss, LÄ. IV, pp. 366-367; Quibbel, ERA, London (1898); Drchain, El-Kab, I, Bruxell (1971); De Meullnaere, in: LÄ. I, pp. 12251277; LGG. IV,pp. 300-304; WPL., pp. 539-541.

(i) $W 3 \underline{d} t \mathrm{~A}$ name for the serpent-goddess Wadjet of Lower Egypt $8-\mathrm{C}_{2}, 8-3$, '80, 844a, i849: Wb. I, 268 (17). $W 3 \underline{d} t$ A name for the red crown of Lower Egypt iog Wb. I, 268 (16). W3dty A name for the tow uraeus Nekhbet and Wadjet 8aथ2; 8ะQ8y. W3dty A name for the double crown rrakh, hink Wb. I, 269 (2). W3 $\underline{d t y} \mathrm{~A}$ name for the double serpent-goddesses of Upper and Lower Egypt Nekhbet and Wadjet (Nekheb and Buto) 's c $^{2}, 88$, \& 3 Wb. I, 269 (3). The goddess Wadjet is called "the green one "or" that of color likes the papyrus plant". She was the greatest goddess who belonged to Delta from prehistory ages as was considered the mistress of the Norths Kingdom before the union of the two parts of Egypt with the goddess Nekhbet, the mistress of Upper Egypt. Her name was discovered on an ivory-label, dating back to the time of king Djer from the first dynasty where she took the forms of a serpent, a lady and a female-vulture bird. The serpent was illustrated on a stela with some 
vessels from Naqada II or Gerza. She presented her breasts like Nekhbet to the lips of the deceased and she suppling him with food and offerings.Pr-w $3 \underline{d} t$ A name for Buto in Delta 5802, , 8 \% Wb. I, 268 (18). Buto is the metropolis of the $6^{\text {th }}$ Nome of Lower Egypt (now Tall ElFaraaeen) is considered her cult center. She was usually depicted in the form of a cobra with Nekhbet in the form of the female-vulture bird upon the two signs of the basket \& (the Nbty title of the king). Such form was followed since the first dynasty. Her sacred symbols were the papyrus plant and the red crown because they were mostly related to Lower Egypt. Martin, LÄ. VI, pp. 865; Fischer, LÄ. VI, pp. 906-911; WPL, pp. 201-209; LGG. II, pp. 257-277.

(j) Sauneron, Esna, II, text 29, pp.73-74.

(k) $\approx$ Bhdt, a name of Edfu; a town in upper Egypt (the ancient $\underline{d} b 3$ ),

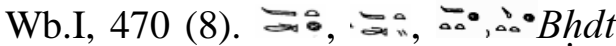
"the one of Edfu", a name for the god from Edfu or the sacred winged sun-disk, Wb.I, 470 (9). Bhdty "the god Horus the Behdetian", Wb.I, 470 (10). His name means" Horus who is from Behdet". Behdet is the metropolis of the $2^{\text {nd }}$ Nome, Upper Egypt $w \underline{t s}-\mathrm{Hr}$, (modern Edfu). It is the most important religious center for its cult, not only in the Egyptian ages, but also in the Ptolemy's and Romans periods. It is originally known as $B h d t$ a name for a town north of Egypt that was called Bhdt mh or sm3 Bhdt and it is the $17^{\text {th }}$ Nome of Lower Egypt (Diospolis). It is currently Tall ElBalamun, where the gods Hor and Soped were worshiped. Archaeological and monumental evidences discovered from the $1^{\text {st }}$ dynasty testified its archaic cult, such as the ivory-comb which has been found in a tomb dating back to the time of the king
Djet, where the god was depicted with two wings of a falcon in a spreading position (Horus the Behdetian or the winged sun-disk). This was given to him as Bhdty in the legend of "the victory of the winged sun-disk in the struggle against his enemies". Otto, LÄ.I, pp. 683; Barta, LÄ.III, pp.33-36; Gardiner, JEA.30; pp.23-56; Fairman, JEA.21, pp.25-30; Alliot, Le Cult de Horus I et II, Le Caire (1949); Cauville, Oxf. Enc. I, pp. 436-438; Vernus, LÄ. VI, pp. 623-631; LGG. II,pp. 812-817, 253-255, 230-298; WPL., pp. 325-326; 668-669; Wb.III, 122124 for the god Horus generally.

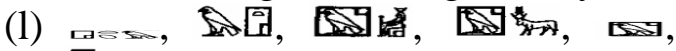

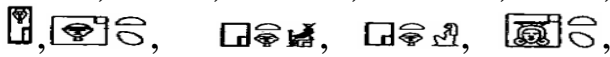
G, 通, n, LGG.V, 75-86. The goddess Hathor was one of the most popular ancient Egyptian goddesses and the beloved deity to all the ancient Egyptians. She was known since prehistory ages especially in the era of Naqada II where she appeared on the pallet of Gerza in the form of a lady with two horns and two ears of a cow. She was connected with the sky and was worshipped with the name Bat, mistress of Hwt-shm (now modern $\mathrm{Hu}$, Nagaa -Hamadi, Qena, Upper Egypt). Her sacred symbol has been carved on a stone-vessel since the 1 st dynasty. In addition, her name, $\mathrm{Hwt}-\mathrm{Hr}$ means "the mansion of Horus", was mentioned in the texts of the Pyramids. She was named this way according to the Osirian myth where she nursed and brought up Horus in the marshes of Delta. Another ancient legend said that Hathor, mistress of the sky, raised her son Horus on her horns to the sky until the goddess Isis took her place. Her original locality is unknown but some think that it may be the Delta because of her nursing for Horus there. Others think that it was Ombos (the modern Tukh, 
Qena, Upper Egypt). Beside she was adored in different ancient Egyptian cities as a popular goddess. In addition to her so-called form as a lady with the sun disk between two horns of a cow, she was illustrated as a cobra-serpent. Her main cult center was Iwnit or T3-ntrt (Tanteris) the metropolis of the $6^{\text {th }}$ Nome of Upper Egypt, the modern Dendera. The goddess Hathor is one of the oldest deities that were known in ancient Egypt as she was mentioned in the texts of the Pyramids. A lot of offerings are presented to her on the river bank. Then her divine boat moves with a big number of the priests. In the company of other boats preceding them the boat of city-ruler and the boats of the pilgrims who accompany the procession move from Dendera towards Edfu. The journey does not complete directly but the goddess's boat stops at Karnak to visit the goddess Mut, the mistress of Asheru. Then, she stops again in a port south of Esna where the cityruler offers foods to the pilgrims. The number of pilgrims who accompany her increases on her way. After that, she stops at Nekhen (El-Kom Alahmar) in order to accompany the god Hour lord of $N h n$. In Edfu, the god Horus and the flag-bearers leave the temple as they wait for the goddess Hathor on the river bank in the company of the city-ruler of Edfu to present offerings and hymens to her. Then, the god Horus accompanies her to the Mamisi. In the morning, ceremonies and rituals begin in the presence of dancers and musicians. After that, the tour of the couple starts inside the temple in which the mummified deities of Amun's ennead were buried. The festivals are continued on the $13^{\text {th }}$ day. On finishing the feast ceremonies, the boats sail back through the same way and pilgrims disperse each towards his city. Pyr. §466a-§546b, §705a; Daumas, LÄ.II, pp. 1024-1033; Vishack, Oxf. Enc. II, pp. 82-85; Derchain, Ph., Hathor Quadrifons, Istanbul (1972); Robert, Cult objects of Hathor, Allam, Beiträge zum HathorKult, MÄS.4; Bonnet, H., Hathor, Rärg, ss. 277-282; Christophe, Fêtes d'Hathor á Edfu , pp. 3, 35, 42.

(m) El damaty, Honor of Jack A. Josephson, p.79.

(n) El damaty, "Die Leeren Kartuschen von Akhenaten", p. 81; Sauneron, Esna II, 25, "Die Leeren 4, 4 (= Nr. 141); 113, 4 (= Nr. 51); 254, 4 (= Nr. 141); Chassinat, Edfou I, 230, 6-7 (d); 231, 3-5 (d).

(o) El damaty, "Die Leeren Kartuschen von Akhenaten", p. 81; Parker, \& Lesko, "The Khonsu Cosmogony", pl. 34; Mendel, MRE. 9, 29 und Taf. 3; Cruz-Uribe; JARCE. 31, p. 170.

(p) El damaty, "Die Leeren Kartuschen von Akhenaten", p. 81; Wb. III, 39, 7; Chassinat, Edfou V (1930), 152, $15 ; 169,14 ; 208,18 ; 233,2 ; 234$, 19; Junker, Philä I, 6, 13, Abb.3; Urk. VIII, 19h ; Mendel, MRE. 9, 29f; Junker, Auszug der Hathor-Tefnut, 37-40.

(q) El damaty, GM. 207, s. 23.

(r) El damaty, GM. 207, s. 23; Cauville, BdÉ. 117, p. 140; Dendara X, pp. $261,10,11,13,15,263,2 ;$ pl. 115 and 144; Chassinat et Daumas, Dendara; Daumas, Dendara; Cauville, Dendara.

(s) El damaty, GM. 207, s. 24; Dendera $\mathrm{X}, 147,11-12$.

(t) El damaty, GM. 207, s. 24; Dendera III, 38, 12, 16; 92, 8,12.

(u) El damaty, GM. 207, s. 24; Dendera $\mathrm{X}, 148,10,146,2,14 ; 147,2,57$. 44,6; 400, 7, 12-13; Chassinat, Edfou VIII, 3,4, 15, 13-16; 16; Edfou VII, 4, $1 ; 43 ; 5,6 ; 6,5 ; 8,7 ; 92 ; 9,5$; Dendara IV, 165, 10, 295, 3-4, Chassinat, Khoiak II, p. 776, Dendara III, 97, 13; IV, 72, 2, Edfou $\mathrm{V}, 361.1$; VI, 283, 7; and also as a title for $H r$-sm3-t3wy: Dendara II, 48, 8; Edfou VII, 3, 7 (= Kurth, Inschriften des Tempels von Edfu s. 
4); kA as name: Junker, Philä I, ss. 169,$15 ; 174,12 ; 185,4 ; 187$, 4; Esna II, 68, 2 (=Nr. 26); Urk. VIII, 69; 109; 636; 896, Edfou II, 140, 10; 142, 14; Kamal, CG 22182 and CG 22188, also CG 22199, in: ZÄS. 107 (1980), p. 87.

(v) El damaty, Deutsches Archäologisches Institut Abteilung Kairo, ss. 81-101; El damaty, OLA. 150, pp. 501-534.

(w) Wb. I, 179 (22), 180 (5), 179 (1721); WPL, pp. 148-151; WPL, pp.150-151; Gardiner, JEA. 30, pp. 46-52; Gardiner \& Peet, T.E., edited by Černy, J., Inscriptions of Sinai, vol. I, London (1955), pl. VII, n. 14.

(x) Budge, Legends of Gods, p. 52; Fairman, JEA. 21, pp. 26-36.

(y) Gardiner, JEA. 30 (1944), p. 40.

(z) For more readings about this myth: Griffith, JEA. 44, pp. 75-85; Fairman, JEA. 21, pp. 26-36; Blackman, \& Fairman, JEA. 28, pp. 32-38; Blackman

\section{References}

[1] Christophe, L., (1955). Les fêtes agraires du calendrier d'Hathor á Edfu, cahiers d'Histoire Egyptien, CHE, Vol. VII, pp: 35-42.

[2] Hölzl, R., (1992). Round topped stelae from the middle kingdom to the late period: Some remarks on the decoration of the lunettes, in: Piacentini, P. (ed.), Atti del VI Congresso Internazionle di Egittologia, Vol. I, Torino, pp: 285-289.

[3] El Damaty, M., (2005). Zur bedeutung der leeren kartuschen, GM, Vol. 207, pp: 23-36.

[4] Winglyph Professional-Glyph for windows electronic program: $N 58$; $N$ 58A; $N$ 6B; $N$ 51; $N$ 51A; $N$ 52; $N$ $58 C ; N 142$.

[5] Faulkner, R., (1962). A concise dictionary of middle Egypt, Griffith Institute Publications, Oxford.

[6] Daumas, F., (2000). Valeurs phonétiques des signes hiéroglyphiques
\& Fairman, JEA. 29, pp. 2-36; Blackman \& Fairman, JEA., pp. 5-22.

(aa) Blackman \& Fairman, JEA. 28, p. 32.

(bb) WPL., p. 150; Hannig , GroßesHandwatabuch ,p.750; Meeks, Annee Lexicographique, I, pp. 338-339; II, p. 343.

(cc) Altenmüller, LÄ. II, cls.148-150; Jacquet- Gordon, RdE. 24, pp.8490; WPL, pp.910-911.

(dd) Meeks, donations, p .5 n.1; Montet, la vie priveé, pp.5-9; Kees, H., Ofertanz, ss. 150-161.

(ee) Chassinat, Dendera, VIII, p.33 (Hathor; 21); 131(2o; 2); 154(III:11);157 (III:10); 149(2o: 2).

(ff) Wilkinson, Reading Egyptian Art, pp.124125; Goedicke, PMMA.20, pp.35-46; Shaw \& Nicholson, British museum dictionary, pp.99-100; Lesko, JARCE.9, pp. 89-101.

(gg) Bains, Fecundity Figures, p. 337.

(hh) PT. 1553-1554.

d'epoque Gréco-Romaine, I-IV, Pub. de la Recherche, Montpellier, Paris.

[7] Gardiner, A., (1949). Egyptian grammar, $3^{\text {rd }}$ ed. revised, Griffith Institute Publications, Oxford.

[8] Leitz, Ch., (2002-2003). Lexikon der Ägyptischen götter und götter Bezeichnungen, $\mathrm{Vol}_{\mathrm{s}}$. I-VIII, Peeters Leiden.

[9] Martin, K., (1986). Uräeus, LÄ, Vol. 6, pp: 864-868.

[10] Sauneron, S., (1958-1982). Le temple d'Esna, IFAO, Le Caire.

[11] Cauville, S., (2001). Edfu, Oxf. Enc., Vol. 1, pp: 436-438; See also, Vernus, P., (1986). Tall Edfu, LÄ, Vol. 6, pp: 623-631.

[12] Robert, M., (1984). Cult objects of Hathor, Oxford Univ. Press, England.

[13] El Damaty, M., (2010). Die leeren Kartuschen von Akhenaten, in: D'Auria S. (ed.), Offering to the Discerning Eye, an Egyptological Medley in Honor of Jack A. Josephson, Leiden, pp: 79-81 
[14] Chassinat, É, (1926-1968), Le temple d'Edfou, IFAO, Le Caire.

[15] Junker, H., (1958). Der grosse pylon des tempels der Isis in Philä, I, Österreichische Akademie der issenschaften, Philosophisch, Vienna.

[16] Cauville, S., (1997). Le temple de Dendara, Le Chapelles Osiriennes, BdÉ. 117, IFAO, Le Caire; See also, Chassinat, É., (1934-52). Le temple de Dendara, Vol . 1-5, IFAO, Le Caire; See also, Chassinat, E. \& Daumas, F., (1965-78). Le temple de Dendara, Vols. 6-8, IFAO, Le Caire; See also, Daumas, F., (1990). Le temple de Dendara, Vol. 9, IFAO, Le Caire; See also, Cauville, S., Le temple de Dendera, IFAO, Cairo.

[17] Chassinat, É., (1968). Le mystère d'Osiris au mois de khoiak, II, IFAO, Le Caire.

[18] El damaty, M., (2011). Die Leeren Kartuschen im Tempel von Edfu, in: Ursula, R-K. \& Tawfik, T. (eds.) Die ihr vorbeigehen werdet ... Wenn Gräber, Tempel und statuen sprechen, Gedenkschrift für prof. Dr. Sayed Tawfik Ahmed. Von Ursula RoßlerKöhler und Tarek Tawfik (Hrsg.), Deutsches Archäologisches Institut Abteilung Kairo, Berlin, New York, pp: 81-101

[19] El damaty, M., (2007). Die leeren Kartuschen aus der regierungszeit von Kleopatra VII. im tempel von Dendera, OLA, Vol. 150, pp: 501-534.

[20] Wilson, P., (1997). A Ptolemaic Lexicon, a lexicographical study of the texts in the temple of Edfu, OLA. 78, Leuven.

[21] Kurth, D., (2004). Die Inschriften des tempels von Edfu / Edfou VII abteilung I übersetzung, Band 2, Harrassowitz, O; Auflage, Wiesbaden; See also, Chassinat, É., (1968). Le mystère d'Osiris au mois de khoiak, II, IFAO, Le Caire.

[22] El damaty, M., (2007). Die leeren Kartuschen aus der regierungszeit von Kleopatra VII. im tempel von Dendera, OLA, Vol. 150, pp: 501-534.

[23] Gardiner, A. \& Peet, T., (1955). Inscriptions of Sinai, Vol. I, Egypt Exploration Society, London.
[24] Budge, W., (1912). The legends of Gods, Mnybks.net, London; See also, Fairman, H., (1935). The myth of Horus at Edfu, I, JEA, Vol. 21, pp. 26-36.

[25] Gardiner, A., (1944). Horus the Behdetite, JEA, Vol. 30, pp: 23-60.

[26] Griffith, J., (1958). The interpretation of Horus myth of Edfu", JEA, Vol. 44, pp: 75-85.

[27] Blackman, A. \& Fairman, H., (1942). The myth of Horus at Edfu-II, JEA, Vol. 28, pp: 2-38.

[28] Hannig, R.، (1995). Die sprache der pharaonen. Großes handwörterbuch Ägyptisch-Deutsch, Mainz; See also, Meeks, D., (1980). Année lexicographique Egypte ancienne, I; 4, Année lexicographique, Paris.

[29] Altenmüller, H., (1977). Feld, geben des feld, $L \ddot{A}$, Vol. II, pp. 148-150; Jacquet-Gordon, H., (1972). A donations stela of Apries, RdE, Vol. 24, pp: 84-90.

[30] Meeks, (1972). Le grand texte des donations au temple d' Edfu, BdE. 59, IFAO, Le Caire; See also, Montet, P., (1925). Les scènes de la vie priveé dans Les tom beaux Égyptiens de L'ancien Empire, These Lettres Lyon, Strasbourg.

[31] Chassinat, É, (1926-1968), Le temple d'Edfou, IFAO, Le Caire; See also, Cauville, S. \& Devauchelle, D., (1985). Le temple d'Edfou,I- XV, IFAO, Le Caire.

[32] Wilkinson, R., (1994). Reading Egyptian art: A hieroglyphic guide to ancient Egyptian painting and sculpture, Thames \& Hudson, London; See also, Goedicke, H., (1971). Reused blocks from the pyramid of Amenemhet I at lisht, PMMA, Vol. 20, pp: 1-162.

[33] Bains, J., (1985). Fecundity figures, Egyptian personification and the Iconology of a Genre, Aris and Phillips Ltd., Warminster.

[34] Sethe, K., (1908-1922). Die Ältaegyptische pyramidentexte, Epigraphik. Leipzig; See also, Faulkner, R., (1970). The ancient Egyptian pyramid texts: Suppllement of Hieroglyphic Texts, Clarendon press, London. 